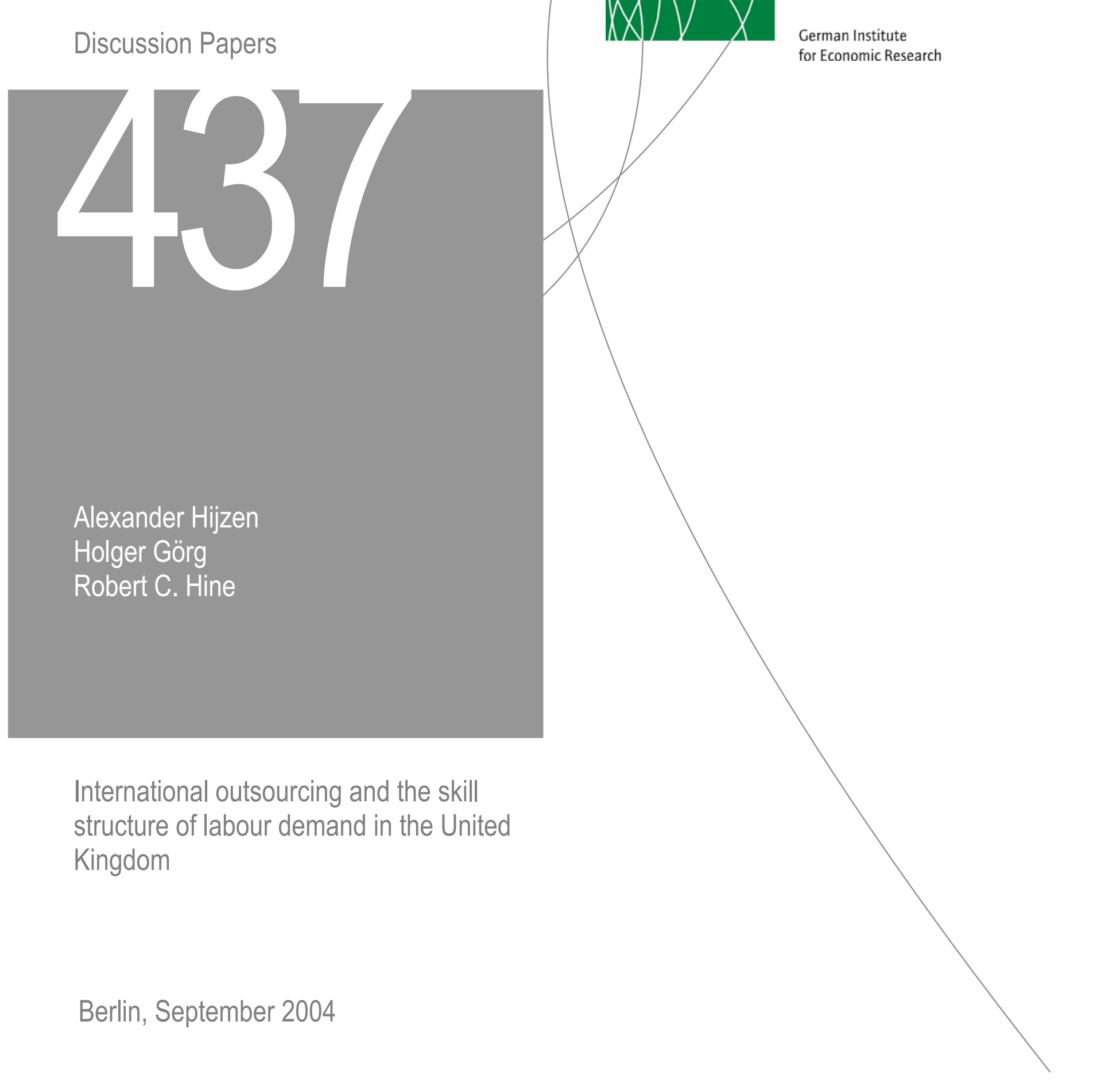


Opinions expressed in this paper are those of the author and do not necessarily reflect views of the Institute.

DIW Berlin

German Institute

for Economic Research

Königin-Luise-Str. 5

14195 Berlin,

Germany

Phone +49-30-897 89-0

Fax $\quad+49-30-89789-200$

www.diw.de

ISSN 1619-4535 


\title{
International outsourcing and the skill structure of labour demand in the United Kingdom
}

\author{
Alexander Hijzen \\ GEP, University of Nottingham \\ Holger Görg \\ GEP, University of Nottingham and DIW Berlin \\ Robert C. Hine* \\ GEP, University of Nottingham
}

\begin{abstract}
This paper investigates empirically the link between international outsourcing and the skill structure of labour demand in the United Kingdom. It is the first detailed study of this issue for the UK. Outsourcing is calculated using import-use matrices of input-output tables for manufacturing industries for the period 1982 to 1996. Estimating a system of variable factor demands, our main results show that international outsourcing has had a strong negative impact on the demand for unskilled labour. Hence, international outsourcing is an important component in explanations of the changing skill structure of manufacturing industries in the United Kingdom.
\end{abstract}

Keywords: Outsourcing, fragmentation, trade, wages, skill-biased technological change

JEL classifications: F14, J31

\footnotetext{
* This paper is forthcoming in the Economic Journal. The authors wish to thank Richard Upward for the provision of the NES data and Sourafel Girma for help with the Census of Production data. Thanks are also due to David Greenaway, Sébastien Jean, Doug Nelson, Peter Wright and an anonymous referee for very helpful comments and suggestions on earlier drafts. All remaining errors are, of course, the authors'. Financial support from the European Commission Fifth Framework Programme (Contract No. HPSE-CT-1999-00017) and the Leverhulme Trust (Programme Grant F114/BF) is gratefully acknowledged.
} 


\section{Introduction}

One of the main consequences of globalisation is the increasing use of international outsourcing of production, i.e., the contracting out of activities that were previously performed within a production unit to foreign subcontractors. ${ }^{1}$ This activity has attracted increasing attention in the popular business press as well as in the academic literature. For example, the Financial Times asserts that: "Subcontracting as many non-core activities as possible is a central element of the new economy" (Financial Times, 31 July 2001, p. 10).

The establishment of international production networks associated with international outsourcing generates trade in intermediates. Some recent studies have provided evidence of the growing importance of trade in intermediates (Campa and Goldberg, 1997; Hummels et al., 2001; Yeats, 2001). From the data for the United Kingdom used in this paper it follows that total international outsourcing in terms of valueadded increased from $33 \%$ in 1984 to $40 \%$ in 1995, while outsourcing within the same industry increased from $11 \%$ to $16 \%$ over the same period.

Outsourcing not only affects the composition of international trade but may also change the pattern of trade. In the international trade literature one of the main driving forces behind outsourcing is the existence of differences in factor prices across national borders (e.g., Feenstra and Hanson, 1996; Kohler, 2004). Unskilled labourintensive stages of production tend to be shifted to unskilled labour-abundant developing countries, while more technologically advanced stages remain in skilled labour-abundant developed countries. As a result the increasing use of international outsourcing enhances the integration of developing countries into the world economy. Indeed for the United Kingdom the share of imports from developing countries over total imports increased from $18 \%$ to $22 \%$ over the period $1982-1996$ indicating increased competition from low-wage countries.

\footnotetext{
${ }^{1}$ There exist many terms that are used to describe the same phenomenon. These are amongst others, vertical specialization (Hummels, Ishii and Yi, 2001), delocalization (Leamer, 1998), fragmentation (Jones and Kierzkowski, 2001). Throughout this paper we use the term "outsourcing".
} 
Many have expressed the fear in developed countries that outsourcing will tend to reduce the demand for relatively unskilled workers resulting in either falling relative wages for, or increased unemployment of, unskilled labour. Some recent examples are the discussions following the decisions by a number of UK manufacturing firms to relocate production to Asia ("Dyson, champion of British industry, switches production to Far East. Surprise decision to shed 800 jobs angers unions and shocks ministers", The Guardian, 6 February 2002; “On your bike Raleigh move to the Far East costs 280 jobs", The Guardian, 29 November 2002; "Speedo Shifts Production from Britain to China", Daily Mail, 30 January 2003). However, from the theoretical literature it is by no means clear that this is always necessarily the case in a general equilibrium setting (e.g., Jones and Kierzkowski, 2001; Kohler, 2004). Moreover, even if a certain theoretical framework suggests an adverse effect on labour markets it is an empirical question whether outsourcing is a sufficiently large phenomenon in order to account for any economically significant labour market effects. It is, therefore, worth analysing the impact of international outsourcing of production on domestic labour markets and in particular on the skill structure of labour demand.

The purpose of this paper is to examine the effects of international outsourcing on the demand for skilled labour in the United Kingdom. While related issues have been examined for a number of developed countries (e.g., Feenstra and Hanson, 1996 for the US; Falk and Koebel, 2001 for Germany; Strauss-Kahn, 2003 for France) there does not appear to be any in-depth analysis for the UK. ${ }^{2}$ This is surprising given that the country experienced rising wage inequality since the $1980 \mathrm{~s}$, even though the causes of this trend are still subject to debate.

Outsourcing differs importantly from import penetration in final goods in the sense that it explicitly takes into account the extent to which firms move production activities abroad. Moreover, labour demand is not only affected in import-competing industries, but in all industries that use foreign inputs. Hence, the impact of

\footnotetext{
${ }^{2}$ Anderton and Brenton (1999) examine the effect of outsourcing on relative wages, but do so by considering all imports from developing countries as outsourcing. Hence, strictly speaking, they do not explicitly measure outsourcing but total imports. Machin and Van Reenen (1998), Haskel and Heden (1999) and Haskel and Slaughter (2001) aim at explaining the increase in UK wage inequality but do not consider the role of international outsourcing. In a related paper Hijzen (2003) looks explicitly at
} 
outsourcing may not be limited to changing labour demands between industries, but also affects the relative demand for labour within industries.

The paper applies and extends the approach of estimating relative demand functions for skilled workers based on a translog cost functions, which is used frequently in the literature (e.g., Feenstra and Hanson, 1996; Strauss-Kahn, 2003). The estimations use input-output data for 50 manufacturing industries for the period 1982-1996. Our main extension to this approach is to go beyond single equation estimates of relative demand for skilled labour by simultaneously estimating a system of four variable factor demands using panel data techniques.

We calculate a detailed measure of international outsourcing from the import-use matrices of the UK input-output tables. This is considered superior to the use of total imports from a particular source country (as used by Anderton and Brenton, 1999) or the calculation of imported intermediate purchases used by Feenstra and Hanson (1996). The inclusion of the $1990 \mathrm{~s}$ in the analysis is also a crucial part of the contribution of this paper as international fragmentation seems to be particularly a phenomenon of the last decade. Finally, labour market data obtained from the New Earnings Survey (NES) allow us to define skill groups on the basis of the Standard Occupational Classification (SOC) instead of the crude distinction between manual and non-manual workers used mostly in the literature.

The remainder of the paper is structured as follows. Section 2 presents the data used and charts the trends in the labour market and in international outsourcing. Section 3 describes the econometric methodology employed in this paper. Section 4 presents and discusses the results of the estimations, while Section 5 gives a short summary and conclusions.

\section{Trends in labour markets and international outsourcing}


This section presents a preliminary review of the relationship between the relative demand for skilled labour and international outsourcing by discussing the data sources and some summary statistics; subsequent sections report and discuss the econometric results.

Labour market data are obtained from the New Earnings Survey Panel Data Set (NESPD). This data set, which is described in more detail in Appendix I, allows one to construct a more accurate measure of skill than the one based on manual/nonmanual workers generally used in the literature (e.g., Feenstra and Hanson, 1996; Machin and Van Reenen, 1998) by using employee information on occupations in accordance with the Standard Occupational Classification (SOC). The SOC distinguishes 9 Major Groups, which rank occupations according to qualifications, training, skills, and experience. The SOC Major Group codes thus provide a natural way to measure skill by relating job types to skill requirements. Following the approach taken by Gregory et al. (2001) we distinguish three skill groups, namely skilled, semi-skilled, and unskilled (see Appendix II).

Data on sales and value added, capital stock as well as prices and quantities of material purchases are obtained from the Census of Production and are described in more detail in Appendix I. Tables 1 and 2 report some summary statistics for the labour market and production data. Table 1 shows the average cost shares of high skilled, semi skilled and unskilled workers $\left(S_{H}, S_{S}, S_{U}\right.$ respectively) and materials $\left(S_{M}\right)$ at the level of the industry (50 industries). It is apparent that the average variable cost shares of labour amount to about $7 \%$ of total variable costs for all three labour types. Materials constitute the lion's share of the variable costs accounting for almost $80 \%$ of total variable costs. ${ }^{3}$

[Table 1 here]

\footnotetext{
${ }^{3}$ Note that these data refer to the industry level. At the country level the labour requirements of domestically supplied materials would also be taken into account.
} 
Table 2 reports average annual changes for the production data for the period 19821996. The table shows that average variable cost shares have been very stable over the sample period, which is in line with the data presented by Haskel and Slaughter (2001) for the UK.

The data on the changes in input quantities and prices, however, imply that there has been a substantial increase in labour market inequality over the period in question. Specifically, while the data show that the absolute quantities for all three types of labour decreased, the reductions in quantities of semi-skilled and unskilled labour have been stronger than the reduction for skilled workers. Hence, we note a relative employment increase by an annual average of about $1.8 \%$ in favour of skilled workers. The ratio between unskilled and semi-skilled workers remained stable. The absolute wage of skilled workers also rose faster than that for the two other skill categories, implying an increase in the relative wage of skilled workers by about $0.6 \%$ per annum.

\section{[Table 2 here]}

The key issue addressed in this paper is whether or not any of this trend towards the use of more skilled labour in manufacturing can be explained by industries engaging in international outsourcing of production. Recently, several studies have attempted to shed light on the development of trade in intermediates world-wide using diverse data sources. Broadly speaking three main sources have been used to document the trend in trade in intermediate inputs: data on outward processing trade, trade statistics on trade in intermediate goods, and input-output tables.

Outward processing trade in the EU or the Offshore Assembly Program in the US refers to the customs arrangement in which complete tariff exemptions or partial levy reductions are granted in accordance to the domestic input content of imported goods. These data have been used by, for example, Görg (2000) and Egger and Egger (2001) for the EU and Feenstra et al. (2000) for the US. In some cases the classification of trade statistics can be used to infer whether trade in some particular industry is trade in intermediate or final goods, as for example in the papers by Yeats (2001) and Hummels et al. (2001). 
For the present purposes input-output tables are considered the most appropriate source as they allow one to analyse developments across industries and time simultaneously. Comparisons over time on the basis of outward processing trade data can be problematic when trade arrangements change. Think for example of the Europe Agreements, which make outward processing trade arrangements increasingly redundant. Comparisons across industries on the basis of the classification of trade statistics seem to be difficult to justify given the different levels of aggregation for different industries.

Input-output tables, however, are also subject to a number of shortcomings. There seem to be two main drawbacks of using input-output tables to analyse outsourcing. First, when focusing on trade in intermediates one necessarily ignores the possibility of outsourcing of the final production stage such as assembly ( $\mathrm{Ng}$ and Yeats, 1999). Second, the data do not capture outsourcing when products are not re-imported, but exported to third markets.

Data on imported intermediate imports are obtained directly from the United Kingdom Input-Output Analytical Tables (I-O ATs), which are compiled approximately every five years by the Office for National Statistics (ONS). The I-O ATs distinguish between intermediate purchases from domestic suppliers ('domestic use matrix') and imported intermediate purchases ('import use matrix'). The present study uses input-output tables for 1984, 1990 and 1995. In addition, from 1992 onwards combined-use matrices are available annually. For more details on the InputOutput data see Appendix I.

Generally, international outsourcing has been defined on the basis of the foreign content of domestic production by taking into account the share of imported intermediate inputs in production. Consequently, the measure has typically been used to asses to what extent workers at home have been substituted by workers abroad, i.e. to evaluate the elasticity of substitution of domestic value-added with respect to imported intermediate inputs. Thus the measure captures the essence of international 
outsourcing, i.e. a firm's decision to substitute domestic value-added by foreign production. 4

We use a narrow definition of international outsourcing which only considers imported intermediates in a given industry from the same industry (which corresponds to diagonal terms of the import-use matrix), i.e.,

(1) $S_{O}^{N}=\frac{O_{i=j, t}}{V A_{j t}}$

where $O$ is imported intermediates in industry $j$ only, and $V A$ is value added in the industry.

Feenstra and Hanson (1999) refer to this as narrow outsourcing. They prefer this measure to broad outsourcing, i.e. imported inputs from all industries, as it is thought to come closer to the essence of fragmentation which necessarily takes place within the industry. The narrow measure of outsourcing seems particularly appropriate at relatively high levels of aggregation. ${ }^{5}$ The motivation to limit oneself to the narrow measure is slightly different here. As we show below we extend the standard translog cost framework only by measures of factor-biased technological change (FBTC), namely outsourcing and innovation activity. It has been widely documented that the increase in the relative demand for skilled labour occurred largely within industries. Consequently, in order to analyse the sources of wage inequality one should concentrate on factors that change relative factor demand within industries. This is exactly what the narrow definition of outsourcing does, while it is not obscured by shifts between domestic and foreign suppliers.

\footnotetext{
${ }^{4}$ Campa and Goldberg (1997) using this measure observe that the ratio of imported intermediates to sales in manufacturing rose from $4 \%$ in 1974 to $8 \%$ in 1993 in the US, from $16 \%$ to $20 \%$ in Canada and from $13 \%$ to $22 \%$ in the UK.

${ }^{5}$ The distinction between narrow and broad outsourcing as introduced by Feenstra and Hanson (1999) may not be without problems as it is entirely based on the way industries are classified. From a fragmentation perspective it can well be the case that industries are classified on an unequal level of disaggregation. Compare for example the two following industries: 'motor vehicles and parts' and 'textiles'. Both industries are classical examples where fragmentation occurs. However, 'automobiles and parts' is represented in the input-output tables for the UK as one single industry, whereas textiles are made up of 10 different industries. As a result the narrow measure of outsourcing will not pick up
} 
We calculate our outsourcing measure directly from the import-use matrices of the input-output tables. By contrast, Feenstra and Hanson $(1996,1999)$ use combined-use matrices in combination with total import penetration ratios calculated from the trade data. Our direct measure may be considered superior to this as it has the advantage that outsourcing is no longer driven by increased import penetration of all goods. After all, increased import penetration refers both to trade in intermediate and trade in final goods. A measure of outsourcing defined as trade in intermediates may therefore be biased when final goods are included, i.e. the significance of outsourcing may be underestimated when trade in intermediates grows faster than trade in final goods.

Table 3 shows descriptive statistics for international outsourcing for the years for which the data are available. In addition to the narrow measure of outsourcing the table also contains information on broad outsourcing and differential outsourcing, i.e. the difference between the broad and narrow definition. Narrow outsourcing was more or less constant during the 1980s around 14-15\% of value-added, but increased during the first half of the 1990 s to $19 \%$ of value-added. Differential outsourcing remained fairly stable over the whole period 1984 to 1995, while broad outsourcing, the sum of narrow and differential outsourcing, also increased from $46 \%$ in 1984 to 49\% in 1995 (reflecting the increase in outsourcing within the same industry).

\section{[Table 3 here]}

An interesting question is whether outsourcing is related to the skill-intensity of the purchasing industry. Traditional trade theory generally emphasises the role of sectorbiased structural change, which refers to the cost-saving effect of outsourcing. Only when it is cost-saving will it be consistent with profit-maximising behaviour. Assuming that the effectiveness of outsourcing is homogenous across industries, the change in outsourcing will be proportional to productivity growth. To the extent that outsourcing contributes to the sector bias of TFP outsourcing is a plausible source of the increase in domestic wage inequality. 
In a specific-factors model (as implicitly assumed in the econometric analysis below given that capital is assumed to be quasi-fixed) the factor bias of outsourcing could also affect relative wages. If one assumes that all imported intermediates are unskilled-intensive the factor bias of outsourcing will on average exert a downward pressure on the relative wage of unskilled workers. This reasoning holds irrespective of the skill-intensity of the purchasing (outsourcing) industry. Thus from a general equilibrium perspective tabulating outsourcing against skill-intensity can only reveal something about its sector bias, not its factor bias.

The last two columns of Table 3 present outsourcing by skill-intensity where skillintensity is defined on the basis of the cost share of skilled labour in the wage bill in 1989. Narrow outsourcing remained more or less constant in importance in the unskilled intensive industries and almost doubled in the skill-intensive industries. One cannot observe a clear pattern for differential outsourcing. Clearly, narrow outsourcing has been subject to a strong sector bias towards the more skill-intensive activities. Unfortunately, no information with regards to the factor bias of outsourcing is available.

\section{Econometric methodology}

In order to investigate econometrically the relationship between international outsourcing and the skill structure of labour demand we start off from the by now standard approach to analysing the relative demand for skilled labour based on the estimation of a translog cost function, introduced by Berman et al. (1994). This approach has been used widely in the literature on the effects of outsourcing on the skilled-unskilled wage differential (e.g., Feenstra and Hanson, 1996; Strauss-Kahn, 2003). However, our methodology departs in two important ways from the standard labour demand regressions a la Berman et al. (1994). 
Firstly, rather than estimating a single cost share equation we estimate a system of demand equations for all variable factors. ${ }^{6}$ We estimate this system simultaneously, which yields more efficient results than single equation estimations when the disturbances are correlated across equations. Given that the right-hand side is identical across equations and that there are cross-equation restrictions this is bound to be the case (Berndt, 1991). In addition, estimating a system of variable factor demands provides more detailed information on the impact of structural change on industry level factor demands. The variable factors are skilled, semi-skilled, unskilled labour, and materials. As in Berman et al. (1994) capital is assumed to be quasi-fixed so that both output and capital can be treated as exogenous in the short-run.

Secondly, while most studies take first differences in order to purge industry-specific time-invariant effects, we apply a fixed-effects (within) estimator to estimate the model. The within estimator emphasises the short run dimension of the data which is consistent with the specification of the restricted or short run cost function. Also it is well known that first-differencing can exacerbate potential problems of measurement error in the data (see Griliches and Hausman, 1986), hence we prefer the fixed effects technique.

We extend the standard translog cost framework to analyse explicitly the impact of factor-biased technological change (FBTC) on relative labour demand, and the sources of FBTC. Two measures of FBTC will be used. Firstly, international outsourcing as described above. Secondly, in order to ensure that the international outsourcing variable does not just pick up the effects of technical change in the industry per se, we include the industry's R\&D intensity. This proxy is intended to pick up technological change in working practices due to the adoption of more sophisticated technologies. Machin and Van Reenen (1998) also include this variable to capture the impact of changes in technology on relative labour demand. Alternative measures of technological change could be computer intensity (Haskel and Heden, 1998) or actual measures of technology adoption (Doms et al., 1997). However, such data are unfortunately not available to us.

\footnotetext{
${ }^{6}$ See Berndt (1991) for an overview of the methodology.
} 
As in Berndt (1991) and Berman et al. (1994) it is assumed that the industry cost functions can be approximated by a translog function, which is twice differentiable, linearly homogenous and concave in factor prices. In general notation, the translog variable (or restricted) cost function can be represented as follows:

(2)

$$
\begin{aligned}
& \ln C_{i}(w, x, z)=\alpha_{0}+\sum_{j=1}^{J} \alpha_{j} \ln w_{i j}+\sum_{k=1}^{K} \beta_{k} \ln x_{i k}+\sum_{r=1}^{R} \gamma_{r} z_{i r}+\frac{1}{2} \sum_{j=1}^{J} \sum_{s=1}^{J} \alpha_{i j} \ln w_{i j} \ln w_{i s} \\
& +\frac{1}{2} \sum_{k=1}^{K} \sum_{l=1}^{K} \beta_{k l} \ln x_{i k} \ln x_{i l}++\frac{1}{2} \sum_{r=1}^{R} \sum_{i=1}^{R} \gamma_{r t} z_{i r} z_{i t}+\frac{1}{2} \sum_{j=1}^{J} \sum_{k=1}^{K} \delta_{j k} \ln w_{i j} \ln x_{i k}+\frac{1}{2} \sum_{j=1}^{J} \sum_{r=1}^{R} \delta_{j r} \ln w_{i j} z_{i r} \\
& +\frac{1}{2} \sum_{k=1}^{K} \sum_{r=1}^{R} \delta_{k r} \ln x_{i k} z_{i r}
\end{aligned}
$$

where $C_{i}$ represents total variable cost in industry $i=1, \ldots, N$, and is a function of factor prices $w_{i j}$ for factor $j=1, \ldots, J$, and industry $i=1, \ldots, N$; fixed inputs and outputs $x_{i k}$ for fixed input or output $k=1, \ldots, K$ in industry $i=1, \ldots, N$; and technological change $z_{i r}$ for proxy $r=r, . ., R$ in industry $i=1, \ldots, N{ }^{7}$ Time subscripts are omitted throughout for ease of presentation. A full set of time dummies is included in order to capture economywide technological change over time.

Constant returns to scale requires that the variable cost function is linearly homogenous in variable factor prices.

(3) $\sum_{j=1}^{J} \alpha_{j}=1$ and $\sum_{j=1}^{J} \alpha_{j s}=\sum_{s=1}^{J} \alpha_{s j}=\sum_{j=1}^{J} \delta_{j k}=\sum_{j=1}^{J} \delta_{j r}=0$

\footnotetext{
${ }^{7}$ Note that $z_{i r}$ do not enter the function in $\log$ form as they are already in percentages.
} 
Without loss of generality symmetry implies that $\alpha_{j s}=\alpha_{s j}{ }^{8}$. Differentiating the translog cost function with respect to factor prices yields the cost share of factor $j$ in total variable costs.

(4) $S_{i j}=\alpha_{j}+\sum_{s=1}^{J} \alpha_{j s} \ln w_{i j}+\sum_{k=1}^{K} \delta_{j k} \ln x_{i k}+\sum_{r=1}^{R} \delta_{j r} z_{i r}, j=1, . ., s, ., J$

where $S_{i j}=\frac{\partial \ln C_{i}}{\partial \ln w_{i j}}=\frac{w_{i j}}{C_{i}} \frac{\partial C_{i}}{\partial w_{i j}}=\frac{w_{i j} x_{i j}}{C_{i}}$ and $\sum_{j=1}^{J} S_{i j}=1$.

The complete system of share equations is estimated using Zellner's method for seemingly unrelated regression equations (SUR). Due to the adding up condition of the variable cost shares the disturbance covariance matrix of the system will be singular and one equation therefore needs to be dropped. The SUR estimates will normally not be invariant to the equation deleted. Fortunately, invariance can be obtained by iterating Zellner's method (ISUR) so that the parameter estimates and residual covariance matrix converge (Berndt and Wood, 1975). ${ }^{9}$ We combine the SUR estimator with panel data estimation techniques to estimate the system given by equation (4) whilst controlling for time-invariant industry-specific effects.

In addition to reporting the results obtained from estimating the variable cost function the elasticities of factor demand will be represented. The elasticity of factor demand $j$ with respect to a change in factor prices is given by:

(5) $\varepsilon_{j s}=\frac{\partial \ln v_{j}}{\partial \ln w_{s}}=\frac{\alpha_{j s}}{s_{j}}+s_{s}-\phi_{j s}, \quad \sum_{j=1}^{N} \varepsilon_{j s}=0$

where $\phi=1$ if $j=s$. The elasticity of factor demand $j$ with respect to a change in the capital stock or output is given by:

\footnotetext{
${ }^{8}$ A Wald-test for the validity of symmetry restrictions could not be rejected.

${ }^{9}$ However, convergence might not always be possible.
} 
(6) $\varepsilon_{j k}=\frac{\partial \ln v_{j}}{\partial \ln x_{k}}=\frac{\delta_{j k}}{s_{j}}, \quad \sum_{l=1}^{M} \varepsilon_{j k}=1$

The elasticity of factor demand with respect to factor-biased technological change due to international outsourcing or R\&D is given by:

(7) $\varepsilon_{j r}=\frac{\partial \ln v_{j}}{\partial z_{r}}=\frac{\delta_{j r}}{s_{r}}, \quad \sum_{k=1}^{M} \varepsilon_{j r}=1$

The command ANALYZ in TSP can used to obtain approximate standard errors (Kohli, 1991). ${ }^{10}$

\section{Results}

Table 4 reports the results of estimating the system of equations using two alternative econometric techniques. Specification 1 uses the pooled iterative Zellner or seemingly unrelated regression estimator (pooled ISUR). Specification 2 accounts for industry fixed effects (fixed effects ISUR). In line with theory, the capital stock is included rather than capital-intensity as is the case in most single-equation studies. The regressions include a full set of time dummies. The $R^{2}$ measure for the goodness of fit reported by most statistical packages applies only to single equation regressions. In a system the $R^{2}$ is no longer constrained between zero and one as system estimators do not share the same objective function (min. e'e). This paper therefore presents the generalised $R^{2}$ as suggested by Berndt (1991). All estimations are performed in TSP.

\section{[Table 4 here]}

The interpretation of the results is not straightforward since the right-hand side variables are in natural logarithms (except for the technological change variables)

\footnotetext{
${ }^{10}$ The command ANALYZ computes the values along with the estimated covariance matrix for a set of non-linear functions of the parameters. The method involves linearising the non-linear functions around the estimated parameter values. Subsequently, the standard formulas for the variance and covariance in the context of linear functions of random variables are used (TSP, 1999).
} 
whereas the dependent variables are not. Results will therefore be discussed on the basis of the estimated price and quantity elasticities. A Hausman test on the performance of the pooled ISUR versus fixed effects ISUR estimator indicates that fixed effects ISUR estimator should be preferred $\left(\chi^{2}(7) \sim 13.575\right.$, Upper tail area: $0.000)$.

The cost functions are well behaved if they are concave in factor prices. If curvature conditions are not satisfied the results are inconsistent with economic theory. Concavity implies that the matrix of second-order derivatives with respect to factor prices is negative semi-definite. A sufficient condition for negative semi-definiteness is that all the principal minors are negative. The translog cost function does not satisfy these properties globally. One should therefore check whether the curvature conditions are satisfied at each observation (Diewert and Wales, 1987). With 750 observations this is not only cumbersome but it is also unlikely that curvature conditions will be satisfied at all points. Instead we require that curvature conditions are on average satisfied. The elasticities are therefore evaluated on the basis of the simple average cost shares across industries (consistent with unweighted regression).

Table 5 reports the price elasticities of factor demand. A necessary but not sufficient condition for concavity in factor prices is that all the own price elasticities are negative (marked bold in the table). Inspection of the signs reveals that elasticities are negative except for the price elasticity of the demand for unskilled labour in the pooled estimation, which is statistically insignificant. The qualitative pattern of the factor demand elasticities is identical for the two sets of results, although quantitatively the elasticities that are obtained from the fixed effects estimates are smaller.

Note that materials are substitutes for all three types of labour. A relatively small reduction in the price of materials can lead to fairly large reductions in the demand for labour. Conversely, a change in wages only has a fairly small impact on the demand for materials. The different types of labour appear to be complements. The results suggest that make-or-buy decisions tend to outweigh substitution effects between variable primary factors. Once the decision has been taken to produce a component in-house the mix of primary inputs is relatively stable. 


\section{[Table 5 here]}

Table 6 reports the remainder of the elasticities that can be obtained from the estimates presented in Table 4. Here, we are particularly interested in the elasticities for outsourcing and R\&D intensity. The latter measure of factor-biased technological change has a positive and significant effect on the demand for skilled workers and a negative effect on the demand for semi-skilled and unskilled workers (although the negative effect is only statistically significant in the pooled regressions); findings that are in line with the results in Machin and Van Reenen (1998) and Haskel and Heden (1999).

Narrow outsourcing has a negative effect on the demand for all types of labour and a positive effect on the demand for materials. Importantly, the impact of international outsourcing is stronger the lower the level of skills. When controlling for industry fixed effects only the elasticity with respect to the demand for unskilled labour is statistically significant. Hence, when analysing the impact of international outsourcing on labour demand it seems important to distinguish between semi-skilled and unskilled workers. Indeed, the most unskilled-intensive activities seem to be most suitable for outsourcing because the potential cost-saving effect is likely to be highest and the need for monitoring and quality control lowest. ${ }^{11}$

A brief examination of the other elasticities shows that capital accumulation has a positive effect on all types of workers, while it has a negative impact on the purchases of materials. Only when accounting for industry fixed effects does capital accumulation disproportionately favour the demand for skilled workers as predicted by the capital-skill complementarity hypothesis. The impact of output on factor demand mirrors qualitatively and to some extent also quantitatively that of capital. ${ }^{12}$

\section{[Table 6 here]}

\footnotetext{
${ }^{11}$ Replacing narrow with broad outsourcing did not produce statistically significant results.

${ }^{12}$ In principle this seems to suggest that constant returns to scale might be a reasonable approximation for the technology. However, the restriction of constant returns to scale was rejected in all cases.
} 
In order to comment on the robustness of these results we present two alternative sets of estimations. Firstly, we use the employment shares instead of cost shares as dependent variables. It has become common practice in single equation factor demand studies to run an additional set of regressions in which the cost shares are replaced by the employment shares in order to highlight the labour market outcome in the presence of labour market rigidities (e.g., Machin and Van Reenen, 1998; Anderton and Brenton, 1999; Strauss-Kahn, 2003).

The factor demand approach is neutral with respect to the channel of adjustment. With perfectly inelastic labour supply, labour markets adjust in response to a labour demand shock by a combination of changes in wages and changes in the output mix. In rigid labour markets, wages and outputs do not adjust to the full extent to clear the labour market. Instead, a relative labour demand shock will be reflected by an increase in unemployment of the factor whose relative demand falls. In practice, one does not observe labour demand shocks, but instead one only observes the change in relative labour demand after wages and employment have adjusted.

Given that when using a translog cost function the dependent variable of the labour demand equation is both a function of wages and employment it is not surprising that an increase in the relative demand for skilled labour has been interpreted as an increase in wage inequality in economies with flexible labour markets such as the US and the UK. Using employment shares instead of cost shares will give the impact of a labour demand shock on factor demand net of wage effects. This specification is therefore only justified when wage adjustment is negligible as may be the case in rigid labour markets. ${ }^{13}$

Table 7 reports the elasticities for the cost and employment share regressions. This system now excludes materials since employment shares can only be constructed for the three types of labour as materials cannot be expressed in comparable units. An interesting consequence of excluding materials is that the different types of labour now act as substitutes rather than complements. This is consistent with the above

\footnotetext{
${ }^{13}$ Put differently, as long as the elasticity of substitution between production and non-production workers exceeds unity changes in cost shares provide a better measure of changes in relative demand than changes in employment shares (Berman, Bound and Griliches, 1994).
} 
explanation that make-or-buy decisions drive the pattern of the elasticities above. Furthermore, we now find from the elasticities based on the cost share estimates that outsourcing only affects low skilled workers, while the elasticities on R\&D remain qualitatively and quantitatively similar to those reported in Table 6.

There does not seem to be a significant difference between the cost and employment share regressions in Table 7. If anything, our results show that the price elasticities of factor demand in the cost share regression tend to be smaller than in the employment regressions. This might indicate that the estimated elasticities obtained with the cost share regression are biased upwards due to simultaneity bias between the labour cost shares and wages. The negative impact of outsourcing on the demand for unskilled workers is smaller in the employment share regressions than in the cost share regressions. This is consistent with findings in previous studies.

\section{[Tables 7 here]}

A second alternative set of regressions replaces the industry level wages by country level wages. Berman et al. (1994) argue that the cross-industry variation of wages reflects only differences in the quality of workers and thus assume that qualityadjusted wages will be constant across industries. They, therefore, suggest that the wage terms can be dropped from the right-hand-side of equation (4) above. In the present case we are dealing with a panel rather than a cross-section. Instead of dropping wages altogether in the last set of results, industry-level wages are replaced by country-level wages.

The motivation for doing so is twofold. Firstly, country-level wages are consistent with the standard version of the specific-factors model. ${ }^{14}$ The specifications estimated above could be considered to reflect the perspective of a labour economist. While capital is fixed in the short-run, the different types of labour can adjust instantaneously. However, in contrast to the specific-factors model, labour markets

\footnotetext{
${ }^{14}$ The prices of materials will also be equalised across industries. However, the data used for the price of materials are indices which take into account the composition of material purchases. The price indices are therefore allowed to change across industries.
} 
continue to be segmented between industries (as reflected by industry level wages). The specific-factors model relaxes the assumption of segmented labour markets but instead assumes that labour is perfectly mobile across sectors. Consequently, wages will be equalised across industries. By replacing industry-level wages by countrylevel wages we thus effectively implement a framework based on the specific-factors model. Secondly, country-level wages are unlikely to be endogenous as no single industry is likely to be large enough to exert a substantial effect on country-level wages. Thus, one would expect the own price elasticities of labour demand to be more negative.

Table 8 represents the elasticities obtained from the cost share regressions with country-level wages using both pooled and fixed effects SUR. Due to multicollinearity between country level wages and time dummies the latter cannot be estimated separately and, hence, comparisons of the estimations with previous results are more difficult. The results change in two directions. Firstly, the own price elasticities of labour demand tend to be more negative, as anticipated. Secondly, while materials continue to act as substitutes for all three types of labour the pattern of elasticities of substitution between the different types of labour changes. In the fixed effects regression, skilled and semi-skilled labour appear to act as substitutes as do semi-skilled and unskilled workers. However, unskilled and skilled workers are apparently so different that they act as each other's complements. The elasticities on outsourcing and R\&D are similar in sign and magnitude to those reported in Table 6.

\section{[Table 8 here]}

\section{Conclusion}

In this paper international outsourcing is related to the debate on trade and wages. Although both the sector and the factor bias of outsourcing are likely to affect relative wages this study focuses exclusively on the factor bias by incorporating outsourcing as a proxy for factor-biased technological change in the factor demand equations. In order to emphasise the factor bias of outsourcing the measure of international outsourcing was constructed on the basis of the diagonal elements of the import-use matrices of the input-output tables. Only imported intermediate purchases from the 
same manufacturing industry are included as such changes induce factor-biased technological change.

Estimating a system of equations for variable cost factors, our main results show that international outsourcing has had a strong negative impact on the demand for unskilled labour in the United Kingdom. R\&D activity, on the other hand, appears to have increased the demand for skilled labour, as has also been found in other studies. Hence, both international outsourcing and technological change induced through $R \& D$ are important components in explanations of the changing skill structure of manufacturing industries in the United Kingdom. The main results are robust to alternative specifications of the econometric model.

\section{References}

Anderton, B. and P. Brenton, "Outsourcing and Low-Skilled Workers in the UK", Bulletin of Economic Research, Vol. 51, No. 4, pp. 267-285.

Baldwin, R.E. and G.G. Cain (2000), "Shifts in Relative U.S. Wages: The Role of Trade, Technology, and Factor Endowments", Review of Economics and Statistics, Vol. 82, pp. 580-595.

Berman, E., J. Bound, and Z. Griliches (1994), "Changes in the Demand for Skilled Labor within U.S. Manufacturing: Evidence from the Annual Survey of Manufacturers", Quarterly Journal of Economics, Vol. 109, pp. 367-397.

Berndt, E.R. (1991), The Practice of Econometrics: Classics and Contemporary, Reading, MA: Addison-Wesley.

Berndt, E.R. and D.O. Wood (1975), “Technology, Prices, and the Derived Demand for Energy", Review of Economics and Statistics, Vol. 57, Iss. 3, pp. 259-268. 
Campa, J. and L.S. Goldberg (1997), "The Evolving External Orientation of Manufacturing Industries: Evidence from four Countries”, Federal Reserve Bank of New York Economic Policy Review, Vol. 3, No. 2, pp. 53-81.

Diewert, W.E. and T.J. Wales, (1987), "Flexible Functional Forms and Global Curvature Conditions", Econometrica, Vol. 55, Iss.1, pp. 43-68.

Doms, M., T. Dunne and K.R. Troske (1997), "Workers, wages and technology", Quarterly Journal of Economics, Vol. 112, pp. 253-290.

Egger, H. and P. Egger (2001), “Cross-border sourcing and outward processing in EU manufacturing", North American Journal of Economics and Finance, Vol. 12, pp. 243-256.

Falk, M. and B.M. Koebel (2001), "Outsourcing, imports and labour demand", Scandinavian Journal of Economics, Vol. 104, pp. 567-586.

Feenstra, R.C. and G.H. Hanson (1996), "Globalization, Outsourcing, and Wage Inequality", American Economic Review, Vol. 86, pp. 240-245.

Feenstra, R.C. and G.H. Hanson (1999), "The Impact of Outsourcing and HighTechnology Capital on Wages: Estimates for the United States, 1979-1990", Quarterly Journal of Economics, Vol. 114, pp. 907-941.

Feenstra, R.C., G.H. Hanson and D.L. Swenson (2000), “Offshore assembly from the United States: Production characteristics of the 9802 program", in R.C. Feenstra (ed.), The Impact of International Trade on Wages, The University of Chicago Press.

Gregory, M., B. Zissimos, and C. Greenhalgh (2001), 'Jobs for the skilled: how technology, trade, and domestic demand changed the structure of UK employment, 1979-1990', Oxford Economic Papers, Vol. 53, No. 1, pp. 20-41.

Griliches, Z. and J. Hausman (1986), "Errors in Variables in Panel Data”, Journal of Econometrics, Vol. 31, pp. 93-118. 
Görg, H. (2000), 'Fragmentation and Trade: US Inward Processing Trade in the EU', Weltwirtschaftliches Archiv, Vol. 136(3), pp. 403-421.

Haskel, J.E. and Y. Heden (1999), "Computers and the Demand for Skilled Labour: Industry- and Establishment-level Panel Evidence for the UK", Economic Journal, Vol. 109, No. 454, pp. 68-79.

Haskel, J.E. and M. Slaughter (2001), "Trade, Technology, and UK Wage Inequality”, Economic Journal, Vol. 111, pp. 163-187.

Hijzen, A. (2003), "Fragmentation, Productivity and Relative Wages in the UK: A Mandated Wage Approach", GEP Research Paper, 2003/17.

Hummels, D., J. Ishii, and K. Yi (2001), "The Nature and Growth of Vertical Specialisation in World Trade", Journal of International Economics, Vol. 54, pp. 7596.

Kohli, U. (1991), Technology, Duality and Foreign Trade: The GNP Function Approach to Modelling Imports and Exports, Hemel Hempstead: Harvester Wheatsheaf.

Jones, R.W. and H. Kierzkowski (2001), “A Framework for Fragmentation”, in S.W. Arndt and H. Kierzkowski, Fragmentation: New Production Patterns in the World Economy, Oxford University Press.

Kohler, W. (2004), "International outsourcing and factor prices with multistage production", Economic Journal, Vo. 114, No. 494, pp. 166-185..

Leamer, E.E. (1998), "In Search of Stolper-Samuelson Linkages between International Trade and Lower Wages", in S.M. Collins (eds.), Imports, Exports, and the American Worker, Washington D.C., Brookings Institution Press, pp. 143-203. 
Machin, S. and J. van Reenen (1998), "Technology and Changes in Skill Structure:

Evidence form Seven OECD Countries", Quarterly Journal of Economics, Vol. 113, pp. $1215-1244$.

Ng, F. and A. Yeats (1999), "Production Sharing in East Asia: Who Does What for Whom and Why?", World Bank Working Paper No. 2197.

Strauss-Kahn, V. (2003), "The Role of Globalization in the Within-Industry Shift Away from Unskilled Workers in France”, NBER Working Paper 9716.

TSP International (1999), Reference Manual, Version 4.5.

Yeats, A.J. (2001), “Just How Big is Global Production Sharing?”, in S.W. Arndt and H. Kierzkowski, Fragmentation: New Production Patterns in the World Economy, Oxford University Press. 


\section{Appendix I: Data}

\section{A1 Description of the New Earnings Survey Panel Data Set}

The NESPD is based on a series of surveys carried out by the Office for National Statistics that covers approximately one percent of the working population. The survey is directed to employers who complete it on the basis of payroll records for the employee for a specific week in April. As the employer and employee are linked via an employee's income tax records the NESPD tends to underrepresent employees whose income falls below the income tax threshold. The present study only takes into account male workers aged between 18-65 that work full-time and are not self-employed.

\section{A2 Description of Input-Output Data}

Data on imported intermediate imports are obtained directly from the United Kingdom Input-Output Analytical Tables (I-O ATs), which are compiled approximately every five years by the Office for National Statistics (ONS). The I-O ATs are derived from the Input-Output Supply and Use Tables (I-O SUTs) which were compiled approximately every five years until 1991 and annually from 1992 onwards. The I-O tables are consistent with National Accounts. The I-O SUTs provide detailed information on the supply and demand for product in terms of industries. Consequently, the I-O SUTs constitute a source of rich information on the interdependence between industries and institutional sectors. The I-O ATs distinguish between intermediate purchases from domestic suppliers ('domestic use matrix') and imported intermediate purchases ('import use matrix'). I-O ATs are symmetric by construction showing the interdependence between either products and products or industries and industries. The present study uses product by product tables, which are recommended as the industry by industry tables are associated with certain conceptual problems that are encountered in the product by product tables. The product by product tables are also less vulnerable to structural change resulting from mergers and acquisitions or fragmentation of production (ONS, 2002). The present study uses input-output tables for 1984, 1990 and 1995. In addition, from 1992 onwards combined-use matrices are available annually. The outsourcing variable is constructed using the following procedure. Imported intermediate purchases are therefore extrapolated using total intermediate purchasing where possible. The remaining gaps are filled up with linear extrapolation.

\section{A3 Description of variables}

Data on sales, value added and capital expenditure are obtained from the Census of Production. Capital stock data are estimated from capital expenditures using the Perpetual Inventory Method (PIM). At least two difficulties arise when estimating the capital stock. First, economic depreciation consists of two elements: physical deterioration due to usage or ageing, and obsolence, which refers to the reduction of efficiency relative to new assets. Second, different types of capital are subject to different rates of depreciation. Oulton and O'Mahony (1994) provide estimates for the total rate of economic depreciation for five different types of capital. In addition, they present estimates of the proportion of capital expenditure on each capital type for various years over the period 1968-1984 for 10 industries. Combining this information it is possible to generate industry-specific depreciation rates. Applying PIM with a pattern of geometric decay gives the following formula:

$$
K_{i t}=\sum_{t-q}^{t}\left(1-\sum_{1}^{k} S_{k} \delta_{k}\right)^{q-1} I_{i, t-q}+\left(1-\sum_{1}^{k} S_{k} \delta_{k}\right)^{t-1979} K_{i, 1979}
$$

The capital stock for industry $i$ at time $t$ equals the sum of expenditure on asset $k$ at time $t$ - $q$ depreciated by the asset-specific economic depreciation rate $\delta_{k}$ plus the depreciated benchmark capital stock. Both the proportion of capital expenditure on each asset, $S_{k}$, and the depreciation rate are assumed constant over time. This way annual capital stock estimates are generated.

Disaggregated data on expenditure on R\&D are only available for the period 1982-1990. For the missing years R\&D is extrapolated using sales. Trade data are obtained from the OECD Trade Database. The trade data are classified according to SITC Rev. 2 and Rev.3. The industry data on sales, value added and capital are classified according to SIC(80) and SIC(92) respectively. Based on product descriptions and industry size a 'best guess' for each SIC(92) industry was obtained. Consequently, industries were regrouped in order to make the classification compatible to the level of aggregation in 
the I-O tables. The correspondence table thus obtained distinguished 53 SIC manufacturing industries. The table should be fairly reliable in both ways. ${ }^{15}$

Import penetration is measured as the value of imports over industry value added. Developed countries include: US, Canada, EU15 (excl. UK), Switzerland, Norway, Japan, Australia and New Zealand. The remaining countries are included in the category developing countries.

${ }^{15}$ The most detailed mapping publicly made available by the CSO, allows just a maximum of 28 industries. This clearly shows that there is a cost of having a larger sample size (Gregory et al., 2001). 


\section{Appendix II: Standard Occupational Classification}

\begin{tabular}{|c|c|c|}
\hline & Major Groups & $\underline{\text { Sub-Major Groups }}$ \\
\hline \multirow[t]{7}{*}{ Skilled } & Managers and Administrators & 1 Corporate Managers and Administrators \\
\hline & & 2 Managers/Proprietors in Agriculture and Services \\
\hline & Professional Occupations & 3 Science and Engineering Professionals \\
\hline & 2 & \\
\hline & & 4 Health Professionals \\
\hline & & 5 Teaching Professionals \\
\hline & & 6 Other Professional Occupations \\
\hline \multirow[t]{13}{*}{$\underline{\text { Semi-skilled }}$} & $\begin{array}{l}\text { Associate Professional and } \\
3 \text { Technical Occupations }\end{array}$ & 7 Science and Engineering Associate Professionals \\
\hline & & 8 Health Associate Professionals \\
\hline & & 9 Other Associate Professional Occupations \\
\hline & $\begin{array}{l}\text { Clerical and Secretarial } \\
4 \text { Occupations }\end{array}$ & 10 Clerical Occupations \\
\hline & & 11 Secretarial Occupations \\
\hline & ${ }_{5}$ Craft and Related Occupations & 12 Skilled Construction Trades \\
\hline & & 13 Skilled Engineering Trades \\
\hline & & 14 Other Skilled Trades \\
\hline & 6 Personal and Protective Service & 15 Protective Service Occupations \\
\hline & Occupations & 16 Personal Service Occupations \\
\hline & Sales Occupations & 17 Buyers, Brokers and Sales Representatives \\
\hline & 7 & \\
\hline & & 18 Other Sales Occupations \\
\hline \multirow[t]{4}{*}{$\underline{\text { Unskilled }}$} & ${ }_{8}^{\text {Plant and Machine Occupations }}$ & $\begin{array}{l}19 \text { Industrial Plants and Machine Operators, } \\
\text { Assemblers }\end{array}$ \\
\hline & & 20 Drivers and Mobile Machine Operators \\
\hline & 9 Other Occupations & $\begin{array}{l}21 \text { Other Occupations in Agriculture, Forestry \& } \\
\text { Fishing }\end{array}$ \\
\hline & & 22 Other Elementary Occupations \\
\hline
\end{tabular}


Table 1: Average cost shares, 1982-1996

\begin{tabular}{lllllll}
\hline \hline & $\underline{\text { Obs }}$ & $\underline{\text { Mean }}$ & & $\underline{\text { Std. Dev. }}$ & $\underline{\text { Min }}$ & $\underline{\text { Max }}$ \\
$S_{H}$ & 750 & 0.0745 & 0.0648 & 0.0025 & 0.3559 \\
$S_{S}$ & 750 & 0.0713 & 0.0521 & 0.0000 & 0.2867 \\
$S_{U}$ & 750 & 0.0702 & 0.0586 & 0.0002 & 0.5255 \\
$S_{M}$ & 750 & 0.7840 & 0.0990 & 0.3227 & 0.9628
\end{tabular}

$\overline{\text { Subscripts refer to high skilled labour, semi-skilled labour, unskilled labour and }}$ materials respectively.

Table 2: Annual percentage change, 1982-1996

\begin{tabular}{|c|c|c|c|c|c|c|}
\hline & & $\underline{\mathrm{Obs}}$ & Mean & Std. Dev. & $\underline{\text { Min }}$ & $\underline{\operatorname{Max}}$ \\
\hline \multicolumn{7}{|l|}{ Cost shares } \\
\hline & $S_{H}$ & 50 & 0.0023 & 0.0056 & -0.0126 & 0.0198 \\
\hline & $S_{S}$ & 50 & 0.0000 & 0.0044 & -0.0173 & 0.0115 \\
\hline & $S_{U}$ & 50 & 0.0010 & 0.0045 & -0.0106 & 0.0139 \\
\hline & $S_{M}$ & 50 & -0.0033 & 0.0052 & -0.0160 & 0.0080 \\
\hline \multicolumn{7}{|c|}{ Input quantities } \\
\hline & $L_{H}$ & 50 & -0.0189 & 0.0535 & -0.2252 & 0.0776 \\
\hline & $L_{S}$ & 50 & -0.0371 & 0.0913 & -0.3098 & 0.1774 \\
\hline & $L_{U}$ & 50 & -0.0367 & 0.1066 & -0.2844 & 0.2644 \\
\hline & $M$ & 50 & 0.0218 & 0.0468 & -0.1064 & 0.1638 \\
\hline \multicolumn{7}{|c|}{ Flexible factor prices } \\
\hline & $W_{H}$ & 50 & 0.0654 & 0.0169 & 0.0164 & 0.1166 \\
\hline & $W_{S}$ & 50 & 0.0583 & 0.0132 & 0.0178 & 0.1032 \\
\hline & $W_{U}$ & 50 & 0.0583 & 0.0173 & 0.0134 & 0.0970 \\
\hline & $P_{M}$ & 50 & 0.0330 & 0.0203 & -0.0162 & 0.1029 \\
\hline \multicolumn{7}{|c|}{ Fixed input and output quantities } \\
\hline & $K$ & 50 & 0.0050 & 0.0361 & -0.0640 & 0.1136 \\
\hline & $Y$ & 50 & 0.0130 & 0.0452 & -0.1173 & 0.1190 \\
\hline
\end{tabular}

Subscripts refer to high skilled labour, semi-skilled labour, unskilled labour and materials respectively. 
Table 3: International outsourcing in 1984, 1990 and 1995

\begin{tabular}{lcccc}
\hline \hline & & Total & $\begin{array}{c}\text { Unskilled- } \\
\text { intensive }\end{array}$ & $\begin{array}{c}\text { Skilled- } \\
\text { intensive }\end{array}$ \\
\hline Narrow & 1984 & 0.152 & 0.173 & 0.122 \\
& 1990 & 0.135 & 0.152 & 0.112 \\
& 1995 & 0.186 & 0.177 & 0.200 \\
Differential & 1984 & 0.308 & 0.288 & 0.335 \\
& 1990 & 0.317 & 0.322 & 0.310 \\
& 1995 & 0.302 & 0.295 & 0.311 \\
Broad & 1984 & 0.459 & 0.461 & 0.457 \\
& 1990 & 0.452 & 0.474 & 0.422 \\
& 1995 & 0.488 & 0.472 & 0.511 \\
\hline \hline
\end{tabular}

Based on unweighted averages. 


\section{$\underline{\text { Pooled SUR }}$}

(a)

\begin{tabular}{lrlrlr}
\hline$\alpha_{H}$ & 0.163 & $(0.035) * *$ & 0.163 & $(0.038) * *$ & 0.001 \\
$\alpha_{S}$ & 0.195 & $(0.028) * *$ & 0.195 & $(0.031) * *$ & 0.009 \\
$\alpha_{U}$ & 0.114 & $(0.030) * *$ & 0.114 & $(0.029) * *$ & 0.017 \\
$\alpha_{H H}$ & 0.002 & $(0.014)$ & 0.002 & $(0.014)$ & 0.038 \\
$\alpha_{H S}$ & -0.037 & $(0.009) * *$ & -0.037 & $(0.012) * *$ & -0.014 \\
$\alpha_{H U}$ & -0.017 & $(0.009) *$ & -0.017 & $(0.010)$ & -0.022 \\
$\alpha_{S S}$ & 0.034 & $(0.011) * *$ & 0.034 & $(0.012) * *$ & 0.046 \\
$\alpha_{S U}$ & -0.022 & $(0.008) * *$ & -0.022 & $(0.010) *$ & -0.024 \\
$\alpha_{U U}$ & 0.069 & $(0.011) * *$ & 0.069 & $(0.012) * *$ & 0.064 \\
$\delta_{H K}$ & 0.020 & $(0.005) * *$ & 0.020 & $(0.004) * *$ & 0.040 \\
$\delta_{H Y}$ & -0.008 & $(0.005)$ & -0.008 & $(0.004) *$ & -0.018 \\
$\delta_{H T}$ & 0.014 & $(0.008)$ & 0.014 & $(0.007) *$ & 0.015 \\
$\delta_{H O}$ & -0.034 & $(0.009) * *$ & -0.034 & $(0.007) * *$ & -0.010 \\
$\delta_{S K}$ & 0.020 & $(0.004) * *$ & 0.020 & $(0.004) * *$ & 0.002 \\
$\delta_{S Y}$ & -0.024 & $(0.004) * *$ & -0.024 & $(0.004) * *$ & -0.011 \\
$\delta_{S T}$ & -0.030 & $(0.007) * *$ & -0.030 & $(0.007) * *$ & -0.002 \\
$\delta_{S O}$ & -0.040 & $(0.007) * *$ & -0.040 & $(0.005) * *$ & -0.016 \\
$\delta_{U K}$ & 0.019 & $(0.004) * *$ & 0.019 & $(0.004) * *$ & 0.004 \\
$\delta_{U Y}$ & -0.030 & $(0.004) * *$ & -0.030 & $(0.004) * *$ & -0.013 \\
$\delta_{U T}$ & -0.031 & $(0.007) * *$ & -0.031 & $(0.010) * *$ & -0.014 \\
$\delta_{U O}$ & -0.044 & $(0.008) * *$ & -0.044 & $(0.006) * *$ & -0.045
\end{tabular}

\section{Fixed effects SUR}

(a)

$\begin{array}{lll}(0.006) & 0.001 & (0.006)\end{array}$

$\begin{array}{lll}(0.006) & 0.009 & (0.008)\end{array}$

$(0.006) * * \quad 0.017 \quad(0.009) *$

$(0.010) * * \quad 0.038 \quad(0.011) * *$

$\begin{array}{lll}(0.007) & -0.014 & (0.009)\end{array}$

$(0.007) * * \quad-0.022 \quad(0.009) *$

$(0.009) * * \quad 0.046 \quad(0.012) * *$

$(0.007) * * \quad-0.024 \quad(0.009) * *$

$(0.010) * * \quad 0.064 \quad(0.012) * *$

$(0.008) * * \quad 0.040 \quad(0.009) * *$

$(0.005) * * \quad-0.018 \quad(0.004) * *$

$(0.007) * \quad 0.015 \quad(0.007) *$

$\begin{array}{lll}(0.013) & -0.010 \quad(0.013)\end{array}$

$\begin{array}{lll}(0.008) & 0.002 \quad(0.008)\end{array}$

$(0.005) * \quad-0.011 \quad(0.007)$

$\begin{array}{lll}(0.007) & -0.002 & (0.009)\end{array}$

$\begin{array}{lll}(0.013) & -0.016 & (0.011)\end{array}$

$\begin{array}{lll}(0.009) & 0.004 & (0.008)\end{array}$

$(0.006) * \quad-0.013 \quad(0.004) * *$

$\begin{array}{lll}(0.008) & -0.014 & (0.011)\end{array}$

$(0.015) * * \quad-0.045 \quad(0.011) * *$

$\begin{array}{lcc}\text { Groups } & 50 & 50 \\ \text { Years } & 15 & 15 \\ \mathrm{~N} & 748 & 748 \\ \widetilde{R}^{2} & 0.407 & 0.534\end{array}$

Notes:

Unweighted regressions, standard errors in parentheses, **, *, refer to $5 \%$ and $1 \%$ significance levels. Subscripts refer to high skilled labour $(\mathrm{H})$, semi-skilled labour $(\mathrm{S})$, unskilled labour (U), materials $(\mathrm{M})$, capital (K), output (Y), R\&D (T) and narrow outsourcing $(\mathrm{O})$ respectively.

$\left.{ }^{a}\right)$ Standard Errors computed from quadratic form of analytic first derivatives (Gauss)

b) Standard Errors computed from heteroscedastic-consistent matrix (Robust-White) 


\begin{tabular}{|c|c|c|c|c|c|c|c|c|}
\hline & \multicolumn{4}{|c|}{ Pooled SUR } & \multicolumn{4}{|c|}{ Fixed effects SUR } \\
\hline & $w_{H}$ & $w_{S}$ & $w_{U}$ & $p_{M}$ & $w_{H}$ & $w_{S}$ & $w_{U}$ & $p_{M}$ \\
\hline$L_{H}$ & $\begin{array}{c}\mathbf{- 0 . 9 0 3} \\
(0.184) \\
* *\end{array}$ & $\begin{array}{c}-0.427 \\
(0.154) \\
* *\end{array}$ & $\begin{array}{l}-0.165 \\
(0.134)\end{array}$ & $\begin{array}{c}1.494 \\
(0.215) \\
* *\end{array}$ & $\begin{array}{c}\mathbf{- 0 . 4 2 1} \\
(0.153) \\
* *\end{array}$ & $\begin{array}{l}-0.120 \\
(0.118)\end{array}$ & $\begin{array}{l}-0.220 \\
(0.123)\end{array}$ & $\begin{array}{c}0.760 \\
(0.109) \\
* *\end{array}$ \\
\hline$L_{S}$ & $\begin{array}{c}-0.446 \\
(0.161) \\
* *\end{array}$ & $\begin{array}{c}\mathbf{- 0 . 4 5 8} \\
(0.162) \\
* *\end{array}$ & $\begin{array}{c}-0.237 \\
(0.135)\end{array}$ & $\begin{array}{c}1.141 \\
(0.177) \\
* *\end{array}$ & $\begin{array}{l}-0.125 \\
(0.124)\end{array}$ & $\begin{array}{c}\mathbf{- 0 . 2 8 4} \\
(0.173)\end{array}$ & $\begin{array}{c}-0.266 \\
(0.121) \\
*\end{array}$ & $\begin{array}{c}0.675 \\
(0.102) \\
* *\end{array}$ \\
\hline$L_{U}$ & $\begin{array}{l}-0.175 \\
(0.142)\end{array}$ & $\begin{array}{l}-0.241 \\
(0.137)\end{array}$ & $\begin{array}{c}0.046 \\
(0.174)\end{array}$ & $\begin{array}{c}0.369 \\
(0.159) \\
* *\end{array}$ & $\begin{array}{c}-0.234 \\
(0.130)\end{array}$ & $\begin{array}{c}-0.270 \\
(0.123) \\
*\end{array}$ & $\begin{array}{c}-\mathbf{0 . 0 1 1} \\
(0.165)\end{array}$ & $\begin{array}{c}0.515 \\
(0.095) \\
* *\end{array}$ \\
\hline$M$ & $\begin{array}{c}0.142 \\
(0.020) \\
* *\end{array}$ & $\begin{array}{c}0.104 \\
(0.016) \\
* *\end{array}$ & $\begin{array}{c}0.033 \\
(0.014) \\
*\end{array}$ & $\begin{array}{c}\mathbf{- 0 . 2 7 8} \\
(0.033) \\
* *\end{array}$ & $\begin{array}{c}0.072 \\
(0.010) \\
* *\end{array}$ & $\begin{array}{c}0.061 \\
(0.009) \\
* *\end{array}$ & $\begin{array}{c}0.046 \\
(0.009) \\
* *\end{array}$ & $\begin{array}{c}\mathbf{- 0 . 1 8 0} \\
(0.014) \\
* *\end{array}$ \\
\hline
\end{tabular}

Notes: The elasticities correspond to the regression results reported in Table 4. Standard errors in parentheses, $* *, *$, refer to $5 \%$ and $1 \%$ significance levels. The standard errors of the elasticities are computed with the command ANALYZ in TSP using the Gaussian standard errors. Black elements refer to the own price elasticities of factor demand. The bold italic elements highlight the own price elasticities that are inconsistent with economic theory.

Table 6: Other elasticities, 1982-1996

\begin{tabular}{|c|c|c|c|c|c|c|c|c|}
\hline & \multicolumn{4}{|c|}{ Pooled SUR } & \multicolumn{4}{|c|}{ Fixed SUR } \\
\hline & $K$ & $\bar{Y}$ & $\overline{R N D}$ & $O U T$ & $K$ & $\bar{Y}$ & $\overline{R N D}$ & $O U T$ \\
\hline$L_{H}$ & $\begin{array}{c}0.272 \\
(0.050) \\
* *\end{array}$ & $\begin{array}{c}-0.110 \\
(0.051) \\
*\end{array}$ & $\begin{array}{c}0.186 \\
(0.092) \\
*\end{array}$ & $\begin{array}{c}-0.453 \\
(0.090) \\
* *\end{array}$ & $\begin{array}{c}0.538 \\
(0.125) \\
* *\end{array}$ & $\begin{array}{c}-0.239 \\
(0.056) \\
* *\end{array}$ & $\begin{array}{c}0.207 \\
(0.094) \\
*\end{array}$ & $\begin{array}{l}-0.135 \\
(0.168)\end{array}$ \\
\hline$L_{S}$ & $\begin{array}{c}0.280 \\
(0.056) \\
* *\end{array}$ & $\begin{array}{c}-0.340 \\
(0.061) \\
* *\end{array}$ & $\begin{array}{c}-0.426 \\
(0.097) \\
* *\end{array}$ & $\begin{array}{c}-0.557 \\
(0.076) \\
* *\end{array}$ & $\begin{array}{c}0.027 \\
(0.116)\end{array}$ & $\begin{array}{l}-0.153 \\
(0.098)\end{array}$ & $\begin{array}{l}-0.029 \\
(0.122)\end{array}$ & $\begin{array}{l}-0.222 \\
(0.154)\end{array}$ \\
\hline$L_{U}$ & $\begin{array}{c}0.271 \\
(0.055) \\
* *\end{array}$ & $\begin{array}{c}-0.428 \\
(0.061) \\
* *\end{array}$ & $\begin{array}{c}-0.436 \\
(0.136) \\
* *\end{array}$ & $\begin{array}{c}-0.623 \\
(0.083) \\
* *\end{array}$ & $\begin{array}{c}0.055 \\
(0.117)\end{array}$ & $\begin{array}{c}-0.180 \\
(0.063) \\
* *\end{array}$ & $\begin{array}{c}-0.205 \\
(0.163)\end{array}$ & $\begin{array}{c}-0.639 \\
(0.158) \\
* *\end{array}$ \\
\hline$M$ & $\begin{array}{c}-0.076 \\
(0.009) \\
* *\end{array}$ & $\begin{array}{c}0.080 \\
(0.010) \\
* *\end{array}$ & $\begin{array}{c}0.060 \\
(0.015) \\
* *\end{array}$ & $\begin{array}{c}0.149 \\
(0.013) \\
* *\end{array}$ & $\begin{array}{c}-0.059 \\
(0.014) \\
* *\end{array}$ & $\begin{array}{c}0.053 \\
(0.010) \\
* *\end{array}$ & $\begin{array}{c}0.001 \\
(0.007)\end{array}$ & $\begin{array}{c}0.090 \\
(0.021) \\
* *\end{array}$ \\
\hline
\end{tabular}

Notes: The elasticities correspond to the regression results reported in Table 4. Standard errors in parentheses, $* *, *$, refer to $5 \%$ and $1 \%$ significance levels. The standard errors of the elasticities are computed with the command ANALYZ in TSP using the Gaussian standard errors. 
Table 7: Elasticities based on cost and employment share regressions, 1982-1996

\begin{tabular}{|c|c|c|c|c|c|c|c|c|}
\hline & \multicolumn{4}{|c|}{ Cost shares with fixed SUR } & \multicolumn{4}{|c|}{ Employment shares with fixed SUR } \\
\hline & $w_{H}$ & $w_{S}$ & $w_{U}$ & & $w_{H}$ & $w_{S}$ & $w_{U}$ & \\
\hline$L_{H}$ & $\begin{array}{c}\mathbf{- 0 . 2 6 7} \\
(0.128) \\
*\end{array}$ & $\begin{array}{c}0.261 \\
(0.106) \\
*\end{array}$ & $\begin{array}{c}0.007 \\
(0.097)\end{array}$ & & $\begin{array}{c}\mathbf{- 0 . 7 8 7} \\
(0.165) \\
* *\end{array}$ & $\begin{array}{c}0.494 \\
(0.150) \\
* *\end{array}$ & $\begin{array}{c}0.293 \\
(0.124) \\
*\end{array}$ & \\
\hline$L_{S}$ & $\begin{array}{c}0.263 \\
(0.106) \\
*\end{array}$ & $\begin{array}{c}\mathbf{- 0 . 2 3 0} \\
(0.130)\end{array}$ & $\begin{array}{c}-0.032 \\
(0.097)\end{array}$ & & $\begin{array}{c}0.347 \\
(0.105) \\
* *\end{array}$ & $\begin{array}{c}\mathbf{- 0 . 5 0 1} \\
(0.133) \\
* *\end{array}$ & $\begin{array}{c}0.153 \\
(0.098)\end{array}$ & \\
\hline \multirow[t]{2}{*}{$L_{U}$} & $\begin{array}{c}0.007 \\
(0.098)\end{array}$ & $\begin{array}{c}-0.032 \\
(0.097)\end{array}$ & $\begin{array}{c}\mathbf{0 . 0 2 6} \\
(0.121)\end{array}$ & & $\begin{array}{c}0.193 \\
(0.082) \\
*\end{array}$ & $\begin{array}{c}0.144 \\
(0.092)\end{array}$ & $\begin{array}{c}\mathbf{- 0 . 3 3 7} \\
(0.110) \\
* *\end{array}$ & \\
\hline & $K$ & $Y$ & $R N D$ & $O U T$ & $K$ & $Y$ & $R N D$ & $O U T$ \\
\hline$L_{H}$ & $\begin{array}{c}0.108 \\
(0.092)\end{array}$ & $\begin{array}{c}0.080 \\
(0.070)\end{array}$ & $\begin{array}{c}0.265 \\
(0.099) \\
* *\end{array}$ & $\begin{array}{c}0.241 \\
(0.141)\end{array}$ & $\begin{array}{c}0.127 \\
(0.107)\end{array}$ & $\begin{array}{c}0.078 \\
(0.083)\end{array}$ & $\begin{array}{c}0.317 \\
(0.120) \\
* *\end{array}$ & $\begin{array}{c}0.285 \\
(0.165)\end{array}$ \\
\hline$L_{S}$ & $\begin{array}{l}-0.129 \\
(0.096)\end{array}$ & $\begin{array}{l}-0.017 \\
(0.064)\end{array}$ & $\begin{array}{c}-0.185 \\
(0.149)\end{array}$ & $\begin{array}{c}0.199 \\
(0.150)\end{array}$ & $\begin{array}{c}-0.110 \\
(0.094)\end{array}$ & $\begin{array}{l}-0.004 \\
(0.063)\end{array}$ & $\begin{array}{l}-0.145 \\
(0.143)\end{array}$ & $\begin{array}{c}0.186 \\
(0.156)\end{array}$ \\
\hline$L_{U}$ & $\begin{array}{c}0.020 \\
(0.098)\end{array}$ & $\begin{array}{l}-0.063 \\
(0.079)\end{array}$ & $\begin{array}{c}-0.082 \\
(0.148)\end{array}$ & $\begin{array}{c}-0.441 \\
(0.176) \\
*\end{array}$ & $\begin{array}{c}0.020 \\
(0.092)\end{array}$ & $\begin{array}{l}-0.048 \\
(0.071)\end{array}$ & $\begin{array}{l}-0.073 \\
(0.136)\end{array}$ & $\begin{array}{c}-0.362 \\
(0.161) \\
*\end{array}$ \\
\hline
\end{tabular}

Notes: Based on unweighted regressions. Standard errors in parentheses, ${ }^{* *},{ }^{*}$, refer to $5 \%$ and $1 \%$ significance levels. The standard errors of the elasticities are computed with the command ANALYZ in TSP using the Gaussian standard errors. Black elements refer to the own price elasticities of factor demand. The bold italic elements highlight the own price elasticities that are inconsistent with economic theory. Materials are excluded. 
Table 8: Elasticities specific-factors model (with labour mobility), 1982-1996

\begin{tabular}{|c|c|c|c|c|c|c|c|c|}
\hline & \multicolumn{4}{|c|}{ Pooled SUR } & \multicolumn{4}{|c|}{ Fixed SUR } \\
\hline & $w_{H}$ & $w_{S}$ & $w_{U}$ & $p_{M}$ & $w_{H}$ & $w_{S}$ & $w_{U}$ & $p_{M}$ \\
\hline$L_{H}$ & $\begin{array}{c}0.271 \\
(0.577)\end{array}$ & $\begin{array}{l}-0.117 \\
(0.675)\end{array}$ & $\begin{array}{l}-0.505 \\
(0.619)\end{array}$ & $\begin{array}{c}0.350 \\
(0.180)\end{array}$ & $\begin{array}{c}\mathbf{- 0 . 5 2 8} \\
(0.450)\end{array}$ & $\begin{array}{c}0.745 \\
(0.599)\end{array}$ & $\begin{array}{c}-0.368 \\
(0.528)\end{array}$ & $\begin{array}{c}0.151 \\
(0.140)\end{array}$ \\
\hline$L_{S}$ & $\begin{array}{l}-0.122 \\
(0.705)\end{array}$ & $\begin{array}{l}\mathbf{- 3 . 3 4 8} \\
(2.341)\end{array}$ & $\begin{array}{c}3.563 \\
(1.871)\end{array}$ & $\begin{array}{c}-0.094 \\
(0.189)\end{array}$ & $\begin{array}{c}0.779 \\
(0.626)\end{array}$ & $\begin{array}{c}-4.776 \\
(2.008) \\
*\end{array}$ & $\begin{array}{c}3.525 \\
(1.604) \\
*\end{array}$ & $\begin{array}{c}0.472 \\
(0.163) \\
* *\end{array}$ \\
\hline$L_{U}$ & $\begin{array}{l}-0.536 \\
(0.657)\end{array}$ & $\begin{array}{c}3.619 \\
(1.901)\end{array}$ & $\begin{array}{l}-\mathbf{2 . 9 7 7} \\
(1.636)\end{array}$ & $\begin{array}{c}-0.106 \\
(0.217)\end{array}$ & $\begin{array}{c}-0.391 \\
(0.560)\end{array}$ & $\begin{array}{c}3.580 \\
(1.630) \\
*\end{array}$ & $\begin{array}{c}-\mathbf{3 . 4 3 1} \\
(1.435) \\
*\end{array}$ & $\begin{array}{c}0.241 \\
(0.205)\end{array}$ \\
\hline$M$ & $\begin{array}{c}0.033 \\
(0.017)\end{array}$ & $\begin{array}{l}-0.009 \\
(0.017)\end{array}$ & $\begin{array}{l}-0.010 \\
(0.019)\end{array}$ & $\begin{array}{c}\mathbf{- 0 . 0 1 5} \\
(0.022)\end{array}$ & $\begin{array}{c}0.014 \\
(0.013)\end{array}$ & $\begin{array}{c}0.043 \\
(0.015) \\
* *\end{array}$ & $\begin{array}{c}0.022 \\
(0.018)\end{array}$ & $\begin{array}{c}\mathbf{- 0 . 0 7 9} \\
(0.013) \\
* *\end{array}$ \\
\hline & $K$ & $Y$ & $R N D$ & $O U T$ & $K$ & $Y$ & $R N D$ & $O U T$ \\
\hline$L_{H}$ & $\begin{array}{c}0.255 \\
(0.057) \\
* *\end{array}$ & $\begin{array}{c}-0.141 \\
(0.064) \\
*\end{array}$ & $\begin{array}{c}0.154 \\
(0.106)\end{array}$ & $\begin{array}{c}-0.482 \\
(0.089) \\
* *\end{array}$ & $\begin{array}{c}0.549 \\
(0.124) \\
* *\end{array}$ & $\begin{array}{c}-0.220 \\
(0.098) \\
*\end{array}$ & $\begin{array}{c}0.416 \\
(0.093) \\
* *\end{array}$ & $\begin{array}{l}-0.181 \\
(0.139)\end{array}$ \\
\hline$L_{S}$ & $\begin{array}{c}0.352 \\
(0.050) \\
* *\end{array}$ & $\begin{array}{c}-0.420 \\
(0.053) \\
* *\end{array}$ & $\begin{array}{c}-0.377 \\
(0.090) \\
* *\end{array}$ & $\begin{array}{c}-0.626 \\
(0.075) \\
* *\end{array}$ & $\begin{array}{c}0.170 \\
(0.104)\end{array}$ & $\begin{array}{c}-0.244 \\
(0.089) \\
* *\end{array}$ & $\begin{array}{c}-0.048 \\
(0.171)\end{array}$ & $\begin{array}{l}-0.112 \\
(0.142)\end{array}$ \\
\hline$L_{U}$ & $\begin{array}{c}0.282 \\
(0.054) \\
* *\end{array}$ & $\begin{array}{c}-0.435 \\
(0.062) \\
* *\end{array}$ & $\begin{array}{c}-0.562 \\
(0.110) \\
* *\end{array}$ & $\begin{array}{c}-0.663 \\
(0.089) \\
* *\end{array}$ & $\begin{array}{c}0.211 \\
(0.138)\end{array}$ & $\begin{array}{l}-0.220 \\
(0.132)\end{array}$ & $\begin{array}{l}-0.107 \\
(0.145)\end{array}$ & $\begin{array}{c}-0.589 \\
(0.157) \\
* *\end{array}$ \\
\hline$M$ & $\begin{array}{c}-0.082 \\
(0.009) \\
* *\end{array}$ & $\begin{array}{c}0.090 \\
(0.009) \\
* *\end{array}$ & $\begin{array}{c}0.070 \\
(0.011) \\
* *\end{array}$ & $\begin{array}{c}0.162 \\
(0.012) \\
* *\end{array}$ & $\begin{array}{c}-0.087 \\
(0.015) \\
* *\end{array}$ & $\begin{array}{c}0.063 \\
(0.014) \\
* *\end{array}$ & $\begin{array}{c}-0.026 \\
(0.011) \\
*\end{array}$ & $\begin{array}{c}0.080 \\
(0.018) \\
* *\end{array}$ \\
\hline
\end{tabular}

Notes: Based on unweighted regressions. Standard errors in parentheses, ${ }^{* *},{ }^{*}$, refer to $5 \%$ and $1 \%$ significance levels. The standard errors of the elasticities are computed with the command ANALYZ in TSP using the Gaussian standard errors. Black elements refer to the own price elasticities of factor demand. The bold italic elements highlight the own price elasticities that are inconsistent with economic theory. No time dummies included. 